Agro-Science Journal of Tropical Agriculture, Food, Environment and Extension Volume 16 Number 1 (January 2017) pp. $11-16$

ISSN 1119-7455

\title{
INFLUENCE OF BREED TYPE AND AGE ON SPERMATOLOGICAL TRAITS OF NIGERIAN LOCAL CHICKENS
}

\author{
Adeoye, G.O., "Oleforuh-Okoleh, V.U. and Chukwuemeka, U.M. \\ Department of Animal Science, Rivers State University, \\ Nkpolu-Oroworukwo, PMB 5080, Port Harcourt, Nigeria
}

*Corresponding author's email: vivian.oleforuh-okoleh@ust.edu.ng; Phone: +234 8080253238

\begin{abstract}
This study evaluated semen quality traits of 36 roosters, comprising 18 roosters each of normal feather and naked neck Nigerian local chicken (NLC) breeds at different ages. The abdominal massage technique was used to collect semen samples from individual roosters at 28, 32, 36 and 40 weeks of age. Individual ejaculates were assessed for semen volume, sperm concentration, total sperm count/ejaculate, motility, morphology and viability. Results of the semen evaluation indicated that except for semen volume, breed of rooster did not statistically influence other spermatological traits studied. The normal feather had higher semen volume $(0.13 \mathrm{~mL})$ than the naked neck roosters. Semen volume, sperm concentration and total sperm count/ejaculate were influenced by age $(p<0.05)$. There was a $44.16 \%$ increase $(p<0.05)$ in semen volume between 28 and 36 weeks of age and $24.67 \%$ decrease by 40 weeks. Sperm concentration was highest at 28 weeks with a decrease of up to $1.32 \times 10^{9} \mathrm{~mL}^{-1}$ at 40 weeks whereas total sperm count/ejaculate was highest at36 weeks of age. Sperm viability ranged from $70.60-80.00 \%$ and did not vary between the two breeds at different ages. It can be concluded that though there exist marginal variations in spermatological traits of the normal feather and naked neck roosters due to their genetic constitution and age, both breeds could still be used efficiently in planning artificial insemination/breeding programmes for genetic improvement of the Nigerian local chicken since the results obtained were within the accepted reference range for chickens.
\end{abstract}

Key words: artificial insemination, naked neck, Nigerian local chicken, normal feather, semen quality

\section{INTRODUCTION}

Local chickens are important in overall food production systems in developing economies mostly because of their adaptation to the tropical environment. They may appear to produce less than highly specialized commercial breeds; however, they possess attributes that make their sustainability on available local resources more ecological and economical in the long term (Oleforuh-Okoleh, 2013; Mkpughe and Bratte, 2015). Incorporation of the Nigerian local chicken as a parent breed stock in the nation's breeding programme is important to meet the increase in poultry product demand by the citizenry. Jie and Liu (2011) reiterated that rapid development of breeding technologies has resulted in enormous progress in the global poultry industry. Such technologies include the use of artificial insemination (AI) which has been considered as a valuable technique in the poultry industry by ensuring effective selection of males and better management of the breeding stock (Benoff et al., 1981; Gebriel et al., 2009). The first successful AI in poultry was in 1899; this was achieved by using semen recovered from the ductus deferens after killing a cock to inseminate hens to produce fertile chicken eggs (Lunak, 2010). Noteworthy, is the fact that AI is more profitable and beneficial when the semen quality is at optimum level. This necessitates that breeding management practices which are beneficial and effective towards proper identification, selection, management and preservation of breeding stocks be undertaken (Lake, 1989). To optimize reproduction output therefore, there is need for periodic evaluation of semen in a breeding stock since only fewer cocks usually run with the hens. Semen evaluation involves quantitative (macroscopic) and qualitative (microscopic) measures of features of the semen and sperm. These features include the appearance and volume of the semen, concentration, motility and morphology of the sperm (Galal, 2007). There have been numerous reports that the semen quality of cocks is influenced by several factors which include nutrition (Tadondjou et al., 2014), season (Ayo et al., 2007; Santiago-Moreno et al., 2011; Elagib et al., 2012), frequency of ejaculation (McDaniel and Sexton, 1977), endocrine disrupting 
chemicals (Rengaraj et al., 2015), photo/lighting period (Bajpai, 1963; Almahdi et al., 2014), physiology (Omeje and Marire, 1990), breed or strain (Molekwa and Umesiobi, 2009; Oke and Ihemeson, 2010; Tarif et al., 2013) and age (Cerolini et al., 1997; Shanmugam et al., 2012). The present study was aimed at investigating the influence of breed type and age on spermatological traits of two Nigerian local chicken breeds (normal feather and naked neck).

\section{MATERIALS AND METHODS \\ Site of Study and Management of Experimental Birds}

The study was done in the Poultry Unit of Department of Animal Science Farm, Rivers State University of Science, Port Harcourt, Nigeria between September and December, 2016. A total of 36 Nigerian local chicken roosters, consisting of 18 roosters each of the normal feather and naked neck breeds, were randomly selected from a heterogeneous local chicken population maintained at the Unit. This population as described in Oleforuh-Okoleh et al. (2016) originated from a parent population of purebred Nigerian local (indigenous) chicken developed at Federal University of Agriculture's PEARL Chicken Research Farm at Abeokuta, Ogun State, Nigeria. The birds were raised on deep litter and transferred to individual battery cages at 20 weeks of age. They were served daily throughout the study period with growers diet $(17.5 \%$ crude protein and 2769 kcal $\mathrm{kg}^{-1}$ metabolizable energy) based on $10 \%$ of the mean weekly body weight of the population. Clean water was given ad libitum. Vaccination against Newcastle disease, fowl pox, fowl typhoid, infectious bronchitis and gumboro diseases were done during their early growth phase. Newcastle disease booster vaccine was administered subsequently every 6 weeks. Vitamins supplement were given once a month via drinking water.

\section{Semen Evaluation}

Prior to actual semen collection, the roosters were primed twice weekly from 24 weeks of age, using the abdominal massage techniques stipulated by Hafez (1987) Spermiogram of the two breeds was done monthly from 28-40 weeks of age, thus a total of 144 semen samples (72 per breed) were evaluated. To achieve this, individual ejaculates were collected into sterile labeled calibrated collection vial of 2-mL capacity. Semen volume was assessed by drawing the ejaculate from the collection vial using calibrated syringe with 0.02 $\mathrm{mL}$ accuracy. The sperm concentration was evaluated using an improved Neubauer haemocytometer as indicated in Hafez (1987). A drop of semen was thoroughly mixed with halfnormal saline using a dilution factor of 1:20. Ten $\mu \mathrm{L}$ of the diluted semen was dropped at each side of the haemocytometer using a micropipette and allowed to settle for $5 \mathrm{~min}$. and then placed under the light microscope under $\times 400$ magnification. Sperm count was done by counting any sperm head that fell within the sub-divided smaller squares at the four edges and centre of the haemocytometer and recording the average. Sperm concentration was obtained by multiplying the number of sperm counted by dilution factor/volume and the multiplying factor of the chambers counted (Bah, 2001). Semen motility was done using a light microscope under $\times 400$ magnification on the basis of the proportion of sperm showing progressive forward movement (Ax et al., 2000). The eosinnegros in differential staining techniques described by Burke (1984) was used to estimate the percentage of live or dead sperms and sperm morphology. Sperm morphology was categorized as either normal form or abnormal form depending on the characteristics of the head, mid--piece and tail region, and also on stage of maturity of the germ cells. The result of active motile sperm and the proportion of live sperm were used to predict sperm viability for individual ejaculate sample.

\section{Statistical Analysis}

Data obtained from the spermiogram were subjected to analysis of variance using multivariate analysis of the general linear model (GLM), with breed and age as fixed factors. Significant means were separated using Duncan (at $\mathrm{p}<0.05$ ). All analyses were done using IBM SPSS (2013).

\section{RESULTS}

\section{Main Effects of Breed and Age} on Spermatological Traits

The main effects of breed and age on semen volume, sperm concentration, total sperm count/ejaculate, sperm motility, sperm morphology, proportion of live and dead sperm and sperm viability are presented in Table 1 . Mean semen volume of $0.52 \pm 0.05 \mathrm{~mL}$ was obtained from the NLC population investigated. Semen volume reported in our study was relatively higher in normal feather roosters $(0.61 \pm 0.05 \mathrm{~mL})$ compared to their naked neck counterpart $(0.48 \pm 0.05 \mathrm{~mL})$. The result further indicates that there was a remarkable increase $(44.16 \%)$ in semen volume between 28 and 36 weeks of age and a reduction $(24.67 \%)$ at 40 weeks of age. Mean sperm concentration and sperm count obtained from both breeds $\left(6.42 \times 10^{9} \mathrm{~mL}^{-1}\right.$ and $3.49 \times 10^{9}$ sperms ejaculate $^{-1}$ respectively) were not influenced by breed type. Aging in roosters was associated with a corresponding significant decrease $(\mathrm{p}<0.05)$ in sperm concentration but with an increase in total sperm count/ejaculate up till 36 weeks of age. Sperm concentration was highest at 28 weeks of age with a decreased of up to $1.32 \times 10^{9} \mathrm{~mL}^{-1}$ by 40 weeks of age. Neither the breed nor the age of 
Adeoye, G.O., Oleforuh-Okoleh, V.U. and Chukwuemeka, U.M.

Table 1: Main effects of breed and age on spermatological traits (mean \pm SEM) of NLC roosters

\begin{tabular}{|c|c|c|c|c|c|c|c|c|}
\hline $\begin{array}{l}\text { Factor/ } \\
\text { Effect }\end{array}$ & $\begin{array}{l}\text { Semen } \\
\text { volume } \\
(\mathrm{ml})\end{array}$ & $\begin{array}{c}\text { Sperm } \\
\text { concentration } \\
\left(\times 10^{9} \mathrm{~mL}^{-1}\right)\end{array}$ & $\begin{array}{c}\text { Sperm } \\
\text { Count } \\
\left(\times 10^{9} \text { ejaculate }^{-1}\right)\end{array}$ & $\begin{array}{c}\text { Sperm } \\
\text { motility } \\
(\%)\end{array}$ & $\begin{array}{c}\text { Normal } \\
\text { morphology } \\
(\%)\end{array}$ & $\begin{array}{c}\text { Dead } \\
(\%)\end{array}$ & $\begin{array}{l}\text { Live } \\
(\%)\end{array}$ & $\begin{array}{c}\text { Viability } \\
(\%)\end{array}$ \\
\hline $\begin{array}{l}\text { Total mean } \\
\text { Breed }\end{array}$ & $0.52 \pm 0.05$ & $6.42 \pm 0.36$ & $3.49 \pm 0.29$ & $70.76 \pm 2.53$ & $76.46 \pm 1.91$ & $18.78 \pm 2.37$ & $81.89 \pm 1.90$ & $75.51 \pm 1.93$ \\
\hline $\begin{array}{l}\text { Normal } \\
\text { feather }\end{array}$ & $0.61 \pm 0.05^{\mathrm{a}}$ & $6.22 \pm 0.42$ & $3.96 \pm 0.41$ & $73.33 \pm 2.68$ & $77.36 \pm 2.11$ & $17.45 \pm 2.66$ & $82.55 \pm 2.67$ & $75.27 \pm 2.31$ \\
\hline $\begin{array}{l}\text { Naked neck } \\
\text { Age (weeks) }\end{array}$ & $0.48 \pm 0.05^{\mathrm{b}}$ & $6.52 \pm 0.42$ & $3.02 \pm 0.42$ & $69.35 \pm 2.71$ & $76.94 \pm 2.13$ & $18.77 \pm 2.69$ & $81.23 \pm 2.69$ & $76.50 \pm 2.28$ \\
\hline 28 & $0.34 \pm 0.06^{\mathrm{c}}$ & $7.01 \pm 0.10^{\mathrm{a}}$ & $2.46 \pm 0.53^{b}$ & $69.36 \pm 3.43$ & $73.97 \pm 1.20$ & $19.61 \pm 3.41$ & $80.39 \pm 3.41$ & $73.75 \pm 2.92$ \\
\hline 32 & $0.49 \pm 0.06^{\mathrm{c}}$ & $6.57 \pm 0.25^{\mathrm{b}}$ & $3.44 \pm 0.54^{b}$ & $72.38 \pm 3.52$ & $76.37 \pm 1.07$ & $18.21 \pm 3.55$ & $81.79 \pm 3.50$ & $76.79 \pm 2.99$ \\
\hline 36 & $0.77 \pm 0.07^{\mathrm{a}}$ & $6.20 \pm 0.13^{\mathrm{b}}$ & $5.11 \pm 0.60^{\mathrm{a}}$ & $73.00 \pm 3.93$ & $77.00 \pm 1.09$ & $19.00 \pm 3.59$ & $81.00 \pm 3.91$ & $75.50 \pm 3.35$ \\
\hline 40 & $0.58 \pm 0.08^{b}$ & $\begin{array}{c}5.69 \pm 0.27^{\mathrm{c}} \\
\text { value }\end{array}$ & $2.93 \pm 0.66^{\mathrm{b}}$ & $\begin{array}{c}70.63 \pm 4.92 \\
\text { p- }\end{array}$ & $81.25 \pm 1.39$ & $15.63 \pm 4.28$ & $84.38 \pm 4.27$ & $77.50 \pm 3.66$ \\
\hline Breed & 0.046 & 0.476 & 0.091 & 0.287 & 0.911 & 0.706 & 0.706 & 0.695 \\
\hline Age & 0.000 & 0.026 & 0.010 & 0.888 & 0.280 & 0.789 & 0.789 & 0.750 \\
\hline
\end{tabular}

${ }^{\mathrm{abc}}$ Means on the same column, for individual effect, not sharing a common superscript are significantly different $(\mathrm{p}<0.05)$.

Table 2: Breed $\times$ age interaction effect $(\mathrm{B} \times \mathrm{A})$ on semen volume and sperm concentration, count/ejaculate and motility ${ }^{1}$

\begin{tabular}{|c|c|c|c|c|c|c|c|c|}
\hline \multirow[b]{2}{*}{ Breed } & \multicolumn{2}{|c|}{$\begin{array}{c}\text { Semen volume } \\
(\mathrm{mL})\end{array}$} & \multicolumn{2}{|c|}{$\begin{array}{l}\text { Sperm concentration } \\
\left(\times 10^{9} \mathrm{~mL}^{-1}\right)\end{array}$} & \multicolumn{2}{|c|}{$\begin{array}{c}\text { Sperm count } \\
\left(\times 10^{9} \text { ejaculate }^{-1}\right)\end{array}$} & \multicolumn{2}{|c|}{$\begin{array}{c}\text { Sperm motility } \\
(\%)\end{array}$} \\
\hline & $n a$ & $\mathrm{Na}$ & $\mathrm{Na}$ & $\mathrm{Na}$ & na & $\mathrm{Na}$ & $n a$ & $\mathrm{Na}$ \\
\hline \multicolumn{9}{|l|}{ Age (weeks) } \\
\hline 28 & $0.33 \pm 0.06$ & $0.35 \pm 0.05$ & $6.50 \pm 0.64$ & $7.52 \pm 0.46$ & $2.31 \pm 0.68$ & $2.61 \pm 0.77$ & $61.22 \pm 4.40^{\mathrm{b}}$ & $77.50 \pm 1.48^{a}$ \\
\hline 32 & $0.58 \pm 0.09$ & $0.41 \pm 0.08$ & $7.50 \pm 0.36$ & $5.64 \pm 0.69$ & $4.32 \pm 0.80$ & $2.57 \pm 0.93$ & $83.33 \pm 2.12^{\mathrm{a}}$ & $61.42 \pm 3.15^{\mathrm{b}}$ \\
\hline 36 & $0.84 \pm 0.08$ & $0.70 \pm 0.07$ & $7.20 \pm 0.52$ & $5.20 \pm 0.32$ & $6.37 \pm 0.84$ & $3.84 \pm 0.84$ & $80.00 \pm 2.98^{\mathrm{a}}$ & $66.00 \pm 2.29^{b}$ \\
\hline 40 & $0.68 \pm 0.10$ & $0.48 \pm 0.09$ & $4.88 \pm 0.48$ & $6.50 \pm 0.26$ & $2.76 \pm 0.84$ & $2.88 \pm 0.84$ & $68.75 \pm 1.28^{\mathrm{b}}$ & $72.50 \pm 1.32^{a}$ \\
\hline$B \times A$ & \multicolumn{2}{|c|}{0.640} & \multicolumn{2}{|c|}{0.087} & \multicolumn{2}{|c|}{0.214} & \multicolumn{2}{|c|}{0.001} \\
\hline
\end{tabular}

${ }^{\mathrm{ab}}$ Means on the same row not sharing a common superscript, for each trait, are significantly different $(\mathrm{p}<0.05)$.

${ }^{1}$ Mean \pm SEM; $n a$ - Normal feather; $N a$ - Naked neck

cocks influenced $(p>0.05)$ the sperm motility. The proportion of live sperm cells in the normal feather and naked feather were 82.55 and $81.23 \%$ respectively, whereas sperm viability ranged from 70.60 to $80.00 \%$. Although, there appeared to be numerical improvement in sperm morphology, proportion of live and dead sperm and sperm viability as the roosters aged, there were no evidences that the breed and age of roosters influenced $(p>0.05)$ these sperm quality traits.

\section{Interaction Effect of Breed $\times$ Age $(B \times A)$ on Spermatological Traits}

The result of breed $\times$ age $(B \times A)$ interaction effects on semen volume, sperm concentration, total sperm count/ejaculate and sperm motility are presented in Table 2. Although normal feather roosters had numerically higher semen concentration at 32 and 36 weeks of age than the naked neck, the variations due to $\mathrm{B} \times \mathrm{A}$ interaction was not significant. Sperm motility ranged from 61.22 to $83.33 \%$ and from 61.42 to $77.50 \%$ in the normal feather and naked neck breeds, respectively. Best sperm motility result was obtained at 32 and 36 weeks of age for the normal feather roosters whereas the naked neck roosters sperm had highest motility rate at 28 and 40 weeks of age $(p<0.05)$.

A significant $(\mathrm{p}<0.05)$ interaction relationship existed between breed and age for sperm morphology and proportion of live and dead sperm (Table 3). The naked neck roosters had better sperm morphology at 28 and 40 weeks of age than normal feather. Much of the variance in the interaction of $\mathrm{B} \times \mathrm{A}$ on proportion of live and dead sperm cells was found between the $28^{\text {th }}$ and $32^{\text {nd }}$ weeks of age. The naked neck appeared to have more live sperm at 28 weeks than the normal feather. The $\mathrm{B} \times \mathrm{A}$ interaction was not observed in sperm viability.

\section{DISCUSSION}

Poultry semen volume compared to other livestock is relatively low because birds lack accessory glands which are well developed in mammals (Almahdi et al., 2014). Although semen volume does not necessarily equate to fertilizing ability or viability of the sperm, the volume cannot be neglected in semen evaluation for the semen serves as the transportation system/medium for the sperm. Our findings refute the report of Galal (2007) which indicated that the presence of the naked neck allele $(\mathrm{Na})$ resulted in significantly higher semen volume compared to its normal feather allele ( $n a)$ in a population of Fayoumi and Dandarawi Egyptian chickens. Hammade et al. (1987) also found that naked neck males produced significantly higher semen volume than their normal counterparts. However, our result, affirms the findings of Peters et al. (2008) and Ajayi et al. (2011) who reported that the semen volume of the normal feather was higher $(0.58-0.83 \mathrm{~mL})$ than those of the naked neck $(0.18-0.37 \mathrm{~mL})$ Nigerian local chicken. The mean semen volume of 0.48 and $0.61 \mathrm{~mL}$ obtained from the naked neck and normal 
Table 3: Breed $\times$ age interaction $(\mathrm{B} \times \mathrm{A})$ effect on sperm morphology, proportion of dead and live sperm, and sperm viability ${ }^{1}$

\begin{tabular}{|c|c|c|c|c|c|c|c|c|}
\hline \multirow[b]{2}{*}{ Breed } & \multicolumn{2}{|c|}{ Normal morphology (\%) } & \multicolumn{2}{|c|}{ Dead sperm (\%) } & \multicolumn{2}{|c|}{ Live sperm (\%) } & \multicolumn{2}{|c|}{ Sperm viability (\%) } \\
\hline & $n a$ & $\mathrm{Na}$ & $n a$ & $\mathrm{Na}$ & $n a$ & $\mathrm{Na}$ & $n a$ & $\mathrm{Na}$ \\
\hline \multicolumn{9}{|l|}{ Age (weeks) } \\
\hline 28 & $68.77 \pm 3.71^{\mathrm{b}}$ & $79.17 \pm 2.09^{\mathrm{a}}$ & $27.56 \pm 4.79^{\mathrm{a}}$ & $11.67 \pm 0.88^{\mathrm{b}}$ & $72.447 \pm 4.51^{\mathrm{b}}$ & $88.33 \pm 5.11^{\mathrm{a}}$ & $70.60 \pm 3.86$ & $77.50 \pm 2.01$ \\
\hline 32 & $79.67 \pm 0.81$ & $73.57 \pm 4.02$ & $10.00 \pm 1.36^{\mathrm{b}}$ & $26.43 \pm 5.41^{\mathrm{a}}$ & $90.007 \pm 5.11^{\mathrm{a}}$ & $73.57 \pm 4.78^{\mathrm{b}}$ & $80.00 \pm 1.80$ & $73.57 \pm 4.07$ \\
\hline 36 & $84.00 \pm 1.37^{\mathrm{a}}$ & $70.00 \pm 1.29^{\mathrm{b}}$ & $16.00 \pm 1.89$ & $22.00 \pm 2.31$ & $84.007 \pm 5.52$ & $78.01 \pm 5.52$ & $81.00 \pm 1.89$ & $70.00 \pm 1.29$ \\
\hline 40 & $77.50 \pm 1.32^{\mathrm{b}}$ & $85.00 \pm 1.18^{\mathrm{a}}$ & $16.25 \pm 0.98$ & $15.00 \pm 1.18$ & $83.757 \pm 6.05$ & $85.07 \pm 6.05$ & $75.00 \pm 2.04$ & $80.00 \pm 1.86$ \\
\hline $\mathrm{B} \times \mathrm{A}$ & \multicolumn{2}{|c|}{0.013} & \multicolumn{2}{|c|}{0.013} & \multicolumn{2}{|c|}{0.013} & \multicolumn{2}{|c|}{0.117} \\
\hline
\end{tabular}

feather roosters respectively was higher than the mean volume of $0.28 \mathrm{~mL}$ reported by Bah et al. (2001) for some Nigerian local breeder roosters and $0.2 \mathrm{~mL}$ by Molekwa and Umesiobi (2009) for South African naked neck indigenous chicken. The semen volume of $0.34 \mathrm{~mL}$ obtained at 28 weeks of age was higher than $0.26 \mathrm{~mL}$ obtained by Shanmugam et al. (2012) from naked neck broiler breeders, of the same age raised in Hyderabad, with significant increase in volume from 24 to 48 weeks of age. Similar volume was obtained by $\mathrm{Hu}$ et al. (2013) in a population of Beijing-You chickens at 43 weeks of age. The variations between our results and some other authors could be attributed to genetic and environmental factors.

Irrespective of the influence of breed or age factor in our study, the mean semen volume $(0.52 \pm 0.05 \mathrm{~mL})$ obtained was above the reference range of $0.1-0.3 \mathrm{~mL}$ given by Long (2006) but within some other accepted range of $0.5-0.8 \mathrm{~mL}$ (Smyth, 1968), 0.4-1.0 mL (Froman et al., 1995) and 0.2-0.5 mL (Getachew, 2016). Low semen volume (hypospermia) is often associated with several factors like blockage of vas deferens or seminal vesicle and hormonal imbalance. Conversely, high semen volume (hyperspermia) is an indication of hormonal imbalance due to the presence of certain steroids (Rengaraj et al., 2015).

The number of sperm found per unit volume $(\mathrm{mL})$ of semen describes the sperm concentration (Malejane et al., 2014). According to Cole and Cupps (1997), this can be used when planning artificial insemination in a flock to predict the number of breeding hens to be inseminated. Mean sperm concentration of $6.42 \times 10^{9} \mathrm{~mL}^{-1}$ obtained from both breeds was similar to the sperm concentration reported by Udeh et al. (2011) in a population of Nigerian local chicken $\left(6.99 \times 10^{6}\right.$ $\mathrm{mL}^{-1}$ ) and by Makhafola et al. (2012) in South African indigenous naked neck cockerels $\left(6.3 \times 10^{9}\right.$ $\left.\mathrm{mL}^{-1}\right)$. Our result which showed that concentration of sperm cells and sperm count per ejaculate was not influenced by genotype affirms the report of Zhang et al. (1999). Previous studies by Machebe and Ezekwe (2002) indicated that the naked neck cocks had higher sperm concentration than the normal feather cocks. Strain differences were also observed with respect to sperm concentration in Denizil cocks by Tuncer et al. (2006). Our finding is higher than the values obtained by Malik et al. (2013) but lower than those reported by Tarif et al. (2013) among four chicken lines (Sasso, Synthetic, Assel RIR and White Rock). Lake (1983) attributed inherent variations in sperm production to differences between individuals within strains and breeds. The decrease in sperm concentration with age as seen in the present study is in line with Cerolini et al. (1997) but contrary to Hermiz et al. (2016) who did not observe any influence of age in semen traits of Iranian roosters belonging to different local genetic groups and their crosses with the commercial strain ISA brown. Our observation that sperm count per ejaculate increased with age agrees with Onuora (1987) and Gebriel et al. (2009).

Sperm morphology is of great value in poultry breeding because it is mostly used in estimating the fertilizing ability of the sperm cells (Lukaszewicz, 1988). Baskt and Brillard (1994) pointed out that only sperms with normal morphology can ascend through the vagina of the hen to the sperm storage tubules. Most often abnormal spermatozoa are found in normal semen analysis but it becomes challenging when there is high proportion of these sperms in the sample, as they possess defects which could affect their ability to fertilize an egg or result in poor hatchability if the egg is fertilized. Our findings on sperm morphology attest to Shanmugam et al. (2012), Almahdi et al. (2014) and Ameen et al. (2014) who reported nonsignificant variation in the sperm morphology in different breeds/strains of cockerels. Tabatabaei et al. (2010) observed an increase in rate of sperm morphological defect in Iranian indigenous broiler breeder chickens with aging of roosters. Tanemura et al. (1993) attributed such defects to impaired spermatids and spermatocytes resulting in interrupted spermatogenesis.

The total motile sperm suggests the total number of sperms assumed to be capable of progressing from the site where semen is deposited in the course of insemination to the sperm storage tubules in the hen. It is a good indicator of a sire's reproductive potential and is often used in predicting fertility (Donoghue et al., 1998). Decreased sperm motility has been associated with abnormal spermatogenesis and epididymal sperm maturation problems (Rengaraj et al., 2015). Sperm motility of the two breeds studied was within the reference range of $60-80 \%$ reported for cockerels in 
Getachew (2016). The non-significant variation observed in sperm motility in the present study disputes the report of Ajayi et al. (2014) who reported differences in the normal feather and naked neck Nigerian local cocks, with the naked neck cocks having better sperm motility. Molekwa and Umesiobi (2009) also reported breed variations in sperm motility in South African indigenous chicken breeds. Gebriel et al. (2009) found higher values for sperm motility in Norfa cocks at 46 weeks of age compared to cocks at 30 and 38 weeks of age. Sperm viability is one of the major components of routine semen quality assessment. Our observations concur with Sonseeda (2014) as well as Mothibedi et al. (2016) who did not observe any difference in sperm viability in between different strains/breeds of chicken.

\section{CONCLUSION}

In poultry breeding, semen evaluation is critical in achieving maximum fertility and hatchability. Our results show that there existed marginal variations in the spermatological traits of the normal feather and naked neck roosters. Much of these variations were due to age. Semen volume was the only trait affected by the breed type. However, since the values obtained from the spermiogram of both breeds at different ages were within the reference range documented for chickens, we infer that any of the two breeds can be used effectively in breeding programmes/schemes aimed at propagating the Nigerian local chicken gene resource.

\section{ACKNOWLEDGEMENT}

We wish to thank the Poultry Unit of Department of Animal Science farm of the University for granting us permission to use its facilities. We also appreciate the assistance of Dr. B. O. Agaviezor and F. Ologbose, of University of Port Harcourt, for training us on semen collection and artificial insemination in chicken. The unrelenting and tireless effort of the laboratory technician, Mr. U. Anusionwu, is worthy of commendation.

\section{REFERENCES}

Ajayi, F.O., Agaviezor, B.O. and Ajuogu, P. K. (2011). Semen characteristics of three strains of local cocks in the humid tropical environment of Nigeria. Int. Jour. of Animal \& Veterinary Advances, 3:125-127

Ajayi, F.O., Agaviezor, B.O. and Ebogomo, D. (2014). Comparative studies of semen and haematology quality of Nigerian indigenous and exotic chicken breeds in the humid tropical zone of Nigeria.Global Journal of Bio-Science \& Biotechnology, 3: 164-168

Almahdi, A.B., Ondho, Y.S. and Sutopo. (2014). Comparative studies of semen quality on different breed of chicken in poultry breeding center Temanggung-Central Java. International Refereed Journal of Engineering and Science, 3: 94-103

Ameen, S.A., Opayemi, O.S., Ajayi, J.A. and Adediwura, M.A. (2014). Evaluation of semen quality of five different cockerel breed used in poultry industry in Nigeria. Journal of Environmental Issues and Agriculture in Developing Countries, 6: 30-36
Ax, R.L., Dally, M., Didion, B.A., and Lenz, R.W. (2000). Semen evaluation. In: B. Hafez and E.S.E. Hafez (Eds.), Reproduction in Farm Animals (pp. 365-375). $7^{\text {th }}$ Ed. Lippincott Williams \& Wilkins, Philadelphia

Ayo, J.O., Owoyele, O.O. and Dzenda, T. (2007). Effects of ascorbic acid on diurnal variations in rectal temperature of BovanNera pullets during the harmattan season. Int. Jour. Poultry Sci., 6: 612-616

Bah, G.S., Chaudhari, S.U.R., and Al-Amin, J.D. (2001). Semen characteristics of local breeder cocks in the Sahel region of Nigeria. Revued'Elevageet de Medicine Veterinaries des pay Tropicaux, 5: 153-158

Bajpai, P.K. (1963). The effect of photoperiodicity on semen characteristics of poultry. Poultry Science, 42: 462-465

Bakst, M.R.G. and Brillard, J.P. (1994). Oviduct spermatozoa selection, transport and storage in poultry. Poultry Science Review, 5: 117-143

Benoff, F. H., Rowe, K., Fuguay, J.I., Renden, J.A. and Scott, A.R. (1981). Effect of semen collector on semen volume and sperm concentration in broiler breeder males. Poultry Science, 60: 1062-1065

Burke, W.H. (1984). Avian reproduction In: M.J. Swenson (Ed.), Duke's Physiology of Domestic Animals. $10^{\text {th }}$ ed. (pp. 847-862). Cornell University Press, New York

Cerolini, S., Kelso, K.A., Noble R.C., Speake, B.K., Pizzi, F. and Cavalchini, L.G. (1997). Relationship between spermatozoa lipid compositon and fertility during aging of chickens. Biology Reprod. 57: 976-980

Cole, H.H. and Cupps, P.T. (1977). Reproduction in Domestic Animals ( $3^{\text {rd }}$ ed). Academic Press. New York. $195 \mathrm{p}$

Donoghue, A.M., Holsberger, D.R., Evenson, D.P. and Froman, D.P. (1998). Semen donor selection by in vitro sperm mobility increases fertility and semen storage in the turkey hen. Journal of Andrology, 19: 295-301. DOI: 10.1002/j.1939-640.1998.tb02008.x

Elagib, H.A.A., Musharaf, N.A., Makawi, S.A. and Mohamed, H.E. (2012). The effects of age and season on semen characteristics of white leghorn cocks under Sudan conditions. International Journal Poultry Science, 11: 47-49

Froman, D.P. and Feltmann, A.J. (1998). Sperm mobility: a quantitative trait of the domestic fowl (Gallus domesticus). Biol. Reproduction, 58: 376-384

Galal, A. (2007). Predicting semen attributes of naked neck and normally feathered male chicken from live performance traits. Int. Jour. Poultry Sci., 6: $36-42$

Gebriel, G.M., Kalamah, M.A., El-Fiky, A., and Ali, F.A. (2009). Some factors affecting semen quality traits in Norfa cocks. Egyptian Poultry Sci., 29: 677-693

Getachew, T. (2016). A review article of artificial insemination in poultry. World's Veterinary Journal, 6: 25-33

Hafez, E.S.E. 1987. Techniques for improving reproductive efficiency. In: Reproduction in Farm Animals, 5th ed. (pp: 455-497). Philadelphia, PA, USA, Lea and Febiger

Hammade, H., Petttjean, M., Douaire, M., Mallard, J., and Mérat, P. (1987). Effet du gène Na (cou nu) chez des coqsélevés à deuxtempératures. II. Caractéristiquesdu sperme et reproduction. Genetique Selection Evolution, 19: 365-380

Hermiz, H.N., Shaker, A.S., Hasafa, B.M.A., Al-Khatib, T.R., Sardary, S.Y. and Toma, J.S. (2016). Evaluation semen characterization of roosters resulted from different local lines and their crosses with ISA brown. Int. Jour. of Agric. Sci., 1: 7-14 
Hu, J., Chen, J.L., Wen, J., Zhao, G.P., Zheng, M.Q., Liu, R.R., Liu, W.P., Zhao, L.H., Liu, G.F. and Wang, Z.W. (2013). Estimation of the genetic parameters of semen quality in Beijing-You chickens. Poultry Science, 92: 2606-2612

IBM SPSS. (2013). IBM SPSS Statistics for Windows, Version 22.0. Armork, NY: IBM Corp.

Jie, H. and Liu, Y.P. (2011). Breeding for disease resistance in poultry: opportunities with challenges. World's Poultry Science Journal, 67: 687-696

Lake, P.E. (1983). Factors affecting fertility level in poultry, with special reference to artificial insemination. Agricultural Research Council, 39: 106-117

Lake, P.E. (1989). Recent progress in poultry reproduction. World's Poultry Science Journal, 45: 53-59. DOI: https://doi.org/10.1079/WPS19890004

Long, J.A. (2006). Avian semen cryopreservation: what are the biological challenges? Poultry Science, 85: 232-236

Lukaszewicz, E. (1988). Study of diluents of cock's semen storage in the light of laboratory estimation and fertility rate (in Polish). Zeszt.Nauk.AR we Wrocławiu, 168: 43-59

Lunak, M. (2010). A brief story of artificial insemination in agriculture/cattle. UNH Cooperative Extension

Machebe, N.S. and Ezekwe, A.G. (2005). Ejaculate characteristics of three genotypes of local cocks in the humid tropics. Agro-Science, 3: 33-37

Makhafola, M.B., Umesiobi, D.O., Mphaphathi, M.L., Masenya, M.B. and Nedambale, T.L. (2012). Characterization of sperm cell motility rate of Southern African indigenous cockerel semen following analysis by sperm class analyzer. Journal of Animal Science Advances, 2: 416-424

Malik, A., Haron, A.W., Yusoff, R.M. Nesa, M., Bukar, M. and Kasim, A. (2013). Evaluation of the ejaculate quality of the red jungle fowl, domestic chicken, and bantam chicken in Malaysia. Turkish Journal of Veterinary and Animal Sciences, 37: 564-568. DOI: 10.3906/vet-1107-26

Malejane, C.M., Greyling, J.C.P. and Raito, M.B. (2014). Seasonal variation in semen quality of Dorper rams using different collection techniques. South African Journal of Animal Science, 44: 26-32

McDaniel, G.R. and Sexton, T.J. (1977). Frequency of semen collection in relation to semen volume, sperm concentration and fertility in the chicken. Poultry Science, 56: 1989-1993. DOI: https://doi.org/10.3382/ps.0561989

Mkpughe, J. I. and Bratte, L. (2015). Effects of breed and frequency of ejaculation on semen characteristics of chickens. Int. Journal of Livestock Res., 5: 42-50. DOI: $10.5455 /$ ijlr.20150406043952

Molekwa, J.T. and Umesiobi, D.O. (2009). Relationships between cock semen viability and the fertility of artificially inseminated South African indigenous chicken breeds. South Afr. Jour. Anim. Sci., 39: 24-28

Mothibedi, K., Nsoso, S.J., Waugh, E.E. and Kgwatalala, P.M. (2016). Semen characteristics of purebred naked neck Tswana and black Australorp $\times$ naked neck Twanacrossbred chickens under an intensive management system in Botswana. American Journal of Research Communication, 4: 38-47

Oke, U.K. and Ihemeson, C. (2010). Effect of genotype on the morphometric differentiation of the reproductive organs and sperm reserves in the Nigerian local chicken. Livestock Res. for Rural Development, 22: Article \#53. Retrieved Sep. 10, 2016, http://www.lrrd.org/lrrd22/3/oke22053.htm
Oleforuh-Okoleh, V.U. (2013).Genetic gains from within-breed selection for egg production traits in a Nigerian local chicken. ARPN Journal of Agricultural and Biological Science, 8: 788-792

Oleforuh-Okoleh, V.U., Nte, I.J. and Onyegbule, Q. (2016). Growth performance and haematological traits of Nigerian local chickens fed varied dietary protein levels. Nigerian Jour. Anim. Prod., 43: 332-342

Omeje, S.S.I. and Marire, B.N. (1990). Evaluation of the semen characteristics of adult cocks of different genetic backgrounds.Theriogenology, 3: 1111-1118

Onuora, G.I. (1987). Body weight, semen quality, and age at sperm production of hemicastrated and intact cockerels (Gallus domesticus). Journals of Reproduction and Fertility, 81: 357-361

Peters S.O., Shoyebo, O.D., Ilori, B.M., Ozoje, M.O., Ikeobi, C.O.N. and Adebambo, O.A. (2008). Semen quality traits of seven strain of chickens raised in humid tropics. Int. Jour. Poultry Sci., 7: 949-953

Rengaraj, D., Kwon, W.S., and Pang, M.G. (2015). Effects of motor vehicle exhaust on male reproductive function and associated proteins. $J$. Proteome Res. 14: 22-37

Santiago-Moreno, J., Castano, C., Toledano-Diaz, A., Coloma, M.A., Lopez-Sebastian, A., Prieto, M.T. and Campo, J.L. (2011). Influence of season on the freezability of free-range poultry semen. Reprod. Dom. Anim., 47: 578-583

Shanmugam, M., Rajkumar, U., Reddy, M.R. and Rama Rao, S.V. (2012). Effect of age on semen quality in naked neck and dwarf chicken under tropical climatic conditions. Animal Production Science, 52: 964-968. ttp://dx.doi.org/10.1071/AN12033

Smyth, J. R., Jr. (1968). Poultry. In: E.J. Perry (Ed.). The Artificial Insemination of Farm Animals (pp. 258300). Rutgers University Press, New Brunswick, N.J.

Sonseeda, P., Vongpralub, T. and Laopaiboon, B. (2013). Effects of environmental factors, ages and breeds on semen characteristics in Thai indigenous chickens: A One-year Study. Thai J Vet Med. 43: 347-352

Tabatabaei, S. Chaji, M. and Mohammadabadi, T. (2010). Correlation between age of rooster and semen quality in Iranian indigenous broiler breeder chickens. Jour. Anim. \& Vet. Advances, 9:195-198

Tadondjou, C.D. , Ngoula, F., Kana, J.R., Defang, H.F., Mube, H.K. and Teguia, A. (2014). Effect of dietary energy level on body weight, testicular development and semen quality of local barred chicken of the western highlands of Cameroon. Advances in Reproductive Sciences, 1: 38-43. http://dx.doi.org/10.4236/arsci.2013.13006

Tanemura, K., Kurohmaru, M., Kuramoto, K., and Hayashi, Y. (1993). Age-related morphological changes in the testis of the BDF1 mouse. Journal of Veterinary Medical Science, 55:703-710

Tarif, A. Md. M.M.T., Mohammad, M.U.B., Raihana, N.F., Nasrin, S.J. and Md. Bazlur, R.M. (2013). Evaluation of semen quality among four chicken lines. IOSR Jour. of Agric. \& Vet. Sci., 6: 7-13

Udeh, I., Ugwu, S.O.C. and Ogagifo, N.L. (2011). Predicting semen traits of local and exotic cocks using body measurements. Asian Journal of Animal Sciences, 5: 268-276

Zhang, X., Berry, W.D., Mcdaniel, G.R., Roland, D.A., Liu, P., Calvert, C. and Wilhite, R. (1999). Body weight and semen production of broiler breeder males as influenced by crude protein levels and feeding regimes during rearing. Poultry Science, 78: 190-196. DOI:10.1093/ps/782.190 